Introduction/Background* Since approval of PARP inhibitor olaparib, testing for germline BRCA $1 / 2$ (gBRCA) gene mutations from blood and testing from formalin-fixed-paraffinembedded (FFPE) tumor tissue for detection of somatic BRCA $1 / 2$ (sBRCA) gene mutation has become standard procedure for patients with high-grade serous ovarian cancer (HGSOC). Since the DNA extracted from FFPE is of poor quality, the new alternative materials are being investigated. Cytological samples (CS) from malignant ascites or other metastatic sites provide intact DNA material for BRCA $1 / 2$ gene testing. The aim of study was to determine if CS can be used for BRCA $1 / 2$ gene testing in patients with HGSOC.

Methodology For patients with HGSOC to be eligible three samples were obtained: blood sample, FFPE (tumor block) and CS from malignant ascites or other metastatic sites. From FFPE and CS status of gBRCA $1 / 2$ or sBRCA $1 / 2$ gene mutations status was obtained, from blood samples status of gBRCA $1 / 2$ gene mutations was obtained. Comparison of reliability in BRCA $1 / 2$ gene testing between all three samples was performed. BRCA $1 / 2$ gene testing was performed by next generation sequencing.

Result(s)* Overall 122 patients were included in the period from 2015-2020, 63 (52\%) of them were eligible for analysis. BRCA $1 / 2$ gene mutation had 21/63 (33\%) of patients: 18 (28\%) gBRCA $1 / 2$ and $3(5 \%)$ sBRCA $1 / 2$ gene mutation. There was $98 \%$ correlation (62/63) between CS and FFPE in determination of BRCA $1 / 2$ gene mutational status. One patient had sBRCA 2 gene mutation present in FFPE but not in CS (ascites).
Conclusion* In experienced oncology centers cytological samples can be used for BRCA $1 / 2$ gene mutation testing in patients with HGSOC.

\section{EVALUATION OF PERIOPERATIVE MANAGEMENT OF ADVANCED OVARIAN (TUBAL/PERITONEAL) CANCER PATIENTS. A SURVEY FROM MITO-MANGO GROUPS}

${ }^{1} S$ Greggi ${ }^{*},{ }^{2} \mathrm{~F}$ Bifulco, ${ }^{3} \mathrm{~A}$ Ferrero, ${ }^{4} \mathrm{P}$ Zola, ${ }^{5} \mathrm{E}$ Busato, ${ }^{6} \mathrm{~N}$ Biglia, ${ }^{7} \mathrm{M}$ Stefanetti, ${ }^{8} \mathrm{~S}$ Danese, ${ }^{9} \mathrm{G}$ Valabrega, "F Falcone. 'Istituto Nazionale Tumori, IRCSS, "Fondazione G. Pascale", Department of Gynecologic Oncology, Italy; ${ }^{2}$ stituto Nazionale Tumori, IRCSS, "Fondazione G. Pascale", Division of Anesthesia and Pain Medicine, Italy; "Mauriziano Hospital, Academic Department Gynaecology and Obstetrics, Italy; ${ }^{4}$ University of Turin, Department of Surgical Sciences, Italy; ${ }^{5}$ Treviso Regional Hospital, Department of Obstetrics and Gynecology, Italy; ${ }^{6}$ Umberto I Hospital, Division of Gynecology and Obstetrics, Italy; ${ }^{7}$ Infermi Hospital, Obstetrics and Gynecology, Italy; ${ }^{8}$ University of Turin, Città della Salute e della Scienza, Gynecology and Obstetrics, Italy; ${ }^{9}$ Candiolo Cancer Institute, FPO-IRCCS, Candiolo, Department of Oncology, Italy

\subsection{6/ijgc-2021-ESG0.338}

Introduction/Background* Enhanced Recovery After Surgery (ERAS) is currently considered as a global surgical quality improvement initiative. There is a paucity of data, however, concerning its application in advanced ovarian cancer (AOC) patients. The present analysis shows the results of a survey aimed at gathering detailed information on current perioperative management of AOC patients within MITO-ManGO Groups.

Abstract 93 Table 1 Survey outcomes compared with the recommendations from the ERAS society

\begin{tabular}{|c|c|c|}
\hline Recommendations from ERAS Society* & $\begin{array}{l}\text { Recommendation } \\
\text { strenght }\end{array}$ & $\begin{array}{l}\text { Centres responding in } \\
\text { accordance with the } \\
\text { recommendation, } \mathrm{n}(\%)\end{array}$ \\
\hline \multicolumn{3}{|l|}{ Preoperative phase } \\
\hline $\begin{array}{l}\text { Preadmission information, education and counselling (including alcohol/smoking cessation and } \\
\text { physical exercise/prehabilitation programs) }\end{array}$ & strong positive & $17(56.7)$ \\
\hline Preoperative anemia $(\mathrm{Hb}<12 \mathrm{~g} / \mathrm{dl})$ : need for screening and treatment & strong positive & $3(10)$ \\
\hline Nutritional screening (supplementation if needed) & strong positive & $5(16.6)$ \\
\hline $\begin{array}{l}\text { Preoperative anaesthetic assessment } \\
\text { Assessment of cardiac risk and function, screening for obstructive sleep apnea, } \\
\text { complete labs, frailty screening }\end{array}$ & strong positive & $11(36.6)$ \\
\hline Pharmacological thromboprophylaxis started 12 hours prior to surgery & strong positive & $23(76.6)$ \\
\hline $\begin{array}{l}\text { Preoperative bowel preparation } \\
\text { low risk for intestinal surgery: mechanical bowel preparation } \\
\text { high risk for intestinal surgery: mechanical bowel preparation } \pm \text { oral antibiotic }\end{array}$ & $\begin{array}{l}\text { weak negative } \\
\text { weak positive }\end{array}$ & $\begin{array}{l}18(60) \\
15(50)\end{array}$ \\
\hline $\begin{array}{l}\text { Preoperative fasting } \\
\quad \text { Light meal until } 6 \text { hours, clear fluids including oral carbohydrate drinks until } 2 \text { hours }\end{array}$ & strong positive & $5(16.6)$ \\
\hline $\begin{array}{l}\text { Pre-anaesthetic medication } \\
\text { Preoperative multimodal analgesia } \\
\text { Sedative/anxiolytics }\end{array}$ & $\begin{array}{l}\text { weak positive } \\
\text { weak negative }\end{array}$ & $\begin{array}{c}25(83.3) \\
18(60) \\
\end{array}$ \\
\hline \multicolumn{3}{|l|}{ Intraoperative phase } \\
\hline Prophylactic antibiotics & strong positive & $30(100)$ \\
\hline Skin preparation by chlorhexidine & strong positive & $19(63.3)$ \\
\hline $\begin{array}{l}\text { Anaesthetic protocol } \\
\text { Epidural analgesia (for }>72 \text { hours after surgery) } \\
\text { Multimodal analgesia } \\
\text { Protective ventilation } \\
\text { Cardiac output monitoring } \\
\text { Deep neuromuscular block and reversal by specific antagonists } \\
\text { Prevention of intraoperative hypothermia } \\
\text { Intraoperative glycaemic control } \\
\text { Advanced monitoring to guide fluid therapy }\end{array}$ & $\begin{array}{l}\text { strong positive } \\
\text { weak positive } \\
\text { strong positive } \\
\text { strong positive } \\
\text { weak positive } \\
\text { strong positive } \\
\text { strong positive } \\
\text { strong positive }\end{array}$ & $\begin{array}{l}21(70) \\
25(83.3) \\
25(83.3) \\
28(93.3) \\
20(66.6) \\
28(93.3) \\
24(80) \\
19(63.3)\end{array}$ \\
\hline Prophylactic abdominal drains & weak positive & $27(90)$ \\
\hline Prophylactic thoracostomy after diaphragmatic peritonectomy \pm full thickness muscle resection & weak positive & $1(3.3)$ \\
\hline Postoperative phase & & \\
\hline Prophylactic nasogastric drainage & weak negative & $16(53.3)$ \\
\hline Avoidance of antibiotic prophylaxis & weak positive & $21(70)$ \\
\hline Early removal of urinary catheter (within the morning of postoperative day 3 ) & strong positive & $30(100)$ \\
\hline $\begin{array}{l}\text { Early oral intake resumption } \\
\text { clear liquids on the day of surgery } \\
\text { solid food from postoperative day } 1\end{array}$ & $\begin{array}{l}\text { strong positive } \\
\text { strong positive }\end{array}$ & $\begin{array}{l}14(46.6) \\
22(73.3)\end{array}$ \\
\hline Mobilisation as early as the day of surgery (out of bed) & strong positive & $0(0)$ \\
\hline $\begin{array}{l}\text { Post-operative nausea and vomiting } \\
\text { Use of antiemetic drugs } \\
\text { Total intravenous anaesthesia }\end{array}$ & $\begin{array}{l}\text { strong positive } \\
\text { weak positive }\end{array}$ & $\begin{array}{c}30(100) \\
6(20)\end{array}$ \\
\hline Pharmacological thromboprophylaxis until 4 weeks after surgery & strong positive & $25(83.3)$ \\
\hline
\end{tabular}




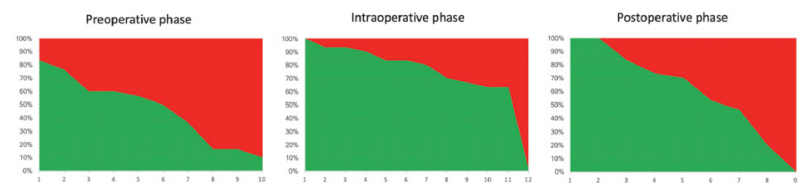

Abstract 93 Figure 1 Concordance between centres' behaviour and ERAS recommendations, expressed by rate of centres behaving in agreement with ERAS recommendations (agreement green; disagreement : red)

Methodology A 60-item questionnaire, covering the ERAS items for perioperative care in cytoreductive surgery, was sent to the responsible for each MITO/ManGO centre. Only questionnaires from centres reporting to operate $>20$ AOC per year were considered for the present analysis.

Result(s)* Thirty/30 (100\%) questionnaires from eligible centres were analysed. Survey main outcomes were presented and compared with the recommendations from the ERAS Society in table 1. Figure 1 graphically shows concordance between centres' current behaviour and ERAS recommendations, expressed by rate of concordance. In particular, $\geq 70 \%$ concordance (rate of centres behaving in agreement with ERAS recommendations) was observed in 2/10, 8/12, and 5/9 items, respectively for the pre, intra and postoperative phase. Conclusion* Although the recent attempts by the health providers to improve the management of AOC patients, this survey shows that further efforts should be made in order to optimize the perioperative pathway. This is true even in selected centres belonging to national oncological networks. There is a need for a structured peri-operative program specifically targeting AOC patients candidate to cytoreductive surgery.

\section{UNDERSTANDING CURRENT MULTIDISCIPLINARY TEAM STRUCTURES AND MANAGEMENT PRACTICES FOR ADVANCED OVARIAN CANCER IN THE UK: THE KNOW- OC SURVEY}

${ }^{1} \mathrm{C}$ Fotopoulou* ${ }^{*}{ }^{2} \mathrm{C}$ Gourley, ${ }^{3} \mathrm{~J}$ Ledermann, ${ }^{4} \mathrm{M}$ Hall, ${ }^{5} \mathrm{~J}$ Ayub, ${ }^{5} \mathrm{~L}$ Fildes, ${ }^{5} \mathrm{~N}$ Roebuck, ${ }^{6} \mathrm{R}$ Lord, ${ }^{7} \mathrm{R}$ Miller, ${ }^{8} \mathrm{~S}$ Sundar. ${ }^{1}$ Hammersmith Hospital, London, UK; ${ }^{2}$ Cancer Research UK Edinburgh Centre, Edinburgh, UK; ${ }^{3}$ UCL Cancer Institute and UCL Hospitals, London, UK; ${ }^{4}$ Mount Vernon Cancer Centre, Northwood, UK; ${ }^{5}$ GSK UK Ltd, Brentford, UK; ${ }^{6}$ Clatterbridge Cancer Centre - Liverpool, Liverpool, UK; ${ }^{7}$ University College London, London, UK; ${ }^{8}$ University of Birmingham, Birmingham, UK

\subsection{6/ijgc-2021-ESG0.339}

Introduction/Background* With increasing availability of multimodality treatment options for advanced ovarian cancer, the role of the multidisciplinary team (MDT) is key. Here, we aim to understand MDT structures and management practices relating to first line $\left(1^{\text {st }}\right.$-line $)$ systemic treatment for advanced ovarian cancer in the UK.

Methodology Structured telephone interviews about current MDT composition and treatment practices in alignment with European (ESMO/ESGO) consensus recommendations for advanced ovarian cancer were conducted in October/November 2020 with 66 healthcare professionals (HCPs) involved in the secondary care of ovarian cancer across the UK $(48.5 \%$ from specialist cancer centres).

Result(s)* Figure 1 and table 1 summarise the staff members regularly attending MDTs and responsibilities across the pathway. While the MDT reviewed $1^{\text {st }}$-line treatment options according to $98.5 \%$ of HCPs; only $66.7 \%$ and $40.9 \%$ said MDTs reviewed treatment after first or second relapse. Before planning $1^{\text {st }}$-line treatment, $C A-125 \quad$ (98.5\%), $\quad g B R C A$ $(\mathrm{n}=81.5 \%)$ and $t B R C A(76.9 \%)$ were the biomarkers most commonly assessed. $90.6 \% \quad(n=58 / 64)$ of HCPs considered $g B R C A / t B R C A$ results to be the most important determinant of prognosis. HRD was the second most important biomarker (55.9\%; $n=33 / 59)$, however, only three HCPs reported routine assessment. The estimated proportion of patients (median $[\mathrm{IQR}] ; \mathrm{n}=54)$ currently treated with $1^{\text {st }}$-line maintenance strategies was: $50 \%$ [26.3-65.0\%] active surveillance; $20.0 \%$ [11.3$33.8 \%]$ bevacizumab and 15\%[10.0-30.0\%] PARP inhibitor (PARPi). Anticipated future eligibility $(n=55)$ was: $35.0 \%$ [22.5-50.0\%]) PARPi maintenance monotherapy; 15.0\% [7.530.0\%] combination PARPi/bevacizumab; 20.0\% [10.0-32.5\%] active surveillance; $10.0 \%$ [8.5-20.0] bevacizumab alone.

Conclusion* The level of MDT involvement in the non-surgical management of advanced ovarian cancer varied depending on pathway and line of relapse. While almost all patients had input from an MDT at initial presentation, less than half of

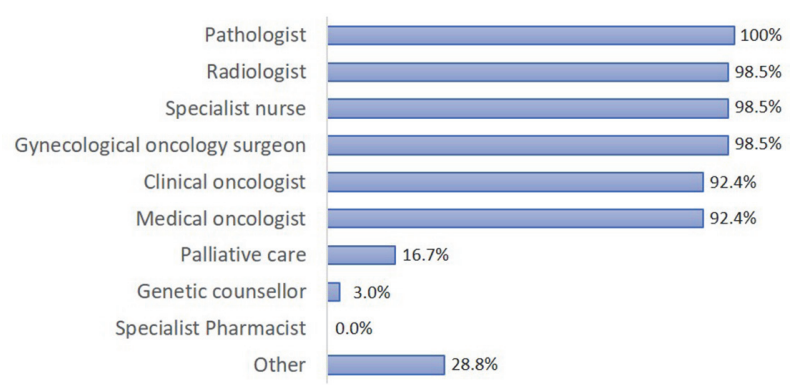

$\begin{array}{llllll}0 & 0 & 20\end{array} \quad 40 \% \quad 60 \% \quad 80 \% \quad 100 \%$

Abstract 109 Figure 1 Responses to question: "which specialties regularly ( $\geq 80 \%$ of time) attend the MDT?"

Abstract 109 Table 1 Responses to question: "Who has overall responsible for the clinical management of patients at each stage in the patient pathway?" ( $\mathrm{N}=66)$

\begin{tabular}{|c|c|c|c|c|c|c|c|}
\hline $\begin{array}{c}\text { Distribution of } \\
\text { ove rall } \\
\text { responsibilities } \\
\text { across pathway, } \\
n(\%)\end{array}$ & $\begin{array}{c}\text { Clinical Team/ } \\
\text { MDT }\end{array}$ & $\begin{array}{l}\text { Gynaecological } \\
\text { Oncology Surgeon }\end{array}$ & $\begin{array}{l}\text { Cancer Unit Lead } \\
\text { Consultant } \\
\text { Gynaecologist }\end{array}$ & Specialist Nurse & $\begin{array}{l}\text { Medical } \\
\text { Oncologist }\end{array}$ & Clinical Oncologist & Other \\
\hline Diagnosis & $18(27.3 \%)$ & $16(24.2 \%)$ & $25(37.9 \%)$ & $0(0.0 \%)$ & $0(0.0 \%)$ & $0(0.0 \%)$ & $7(10.6 \%)$ \\
\hline Staging & $45(68.2 \%)$ & $8(12.1 \%)$ & $8(12.1 \%)$ & $1(1.5 \%)$ & $0(0.0 \%)$ & $0(0.0 \%)$ & $4(6.1 \%)$ \\
\hline $\begin{array}{l}\text { Surgical } \\
\text { intervention }\end{array}$ & $8(12.1 \%)$ & $50(75.8 \%)$ & $6(9.1 \%)$ & $0(0.0 \%)$ & $0(0.0 \%)$ & $0(0.0 \%)$ & $2(3.0 \%)$ \\
\hline First Line & $19(28.8 \%)$ & $1(1.5 \%)$ & $2(3.0 \%)$ & $0(0.0 \%)$ & $28(42.4 \%)$ & $3(4.5 \%)$ & $13(19.7 \%)$ \\
\hline $\begin{array}{l}\text { Treatment at } \\
\text { recurrence }\end{array}$ & $19(28.8 \%)$ & $0(0.0 \%)$ & $0(0.0 \%)$ & $0(0.0 \%)$ & $34(51.5 \%)$ & $3(4.5 \%)$ & $10(15.2 \%)$ \\
\hline Palliative care & $17(25.8 \%)$ & $2(3.0 \%)$ & $0(0.0 \%)$ & $0(0.0 \%)$ & $17(25.8 \%)$ & $3(4.5 \%)$ & $27(40.9 \%)$ \\
\hline
\end{tabular}

